Studia z Dziejów Średniowiecza nr 21, 2017

\author{
Sobiesław Szybkowski \\ (Gdańsk)
}

\title{
Dwa niedrukowane dokumenty byszewskie (koronowskie) z XIV w.
}

Key words: medieval Cuiavia, Cistercian Order, medieval polish nobility

Kujawy i ziemia dobrzyńska jako dzielnice średniowiecznego Królestwa Polskiego do chwili obecnej nie doczekały się nowoczesnego dyplomatariusza. Z zapowiadanego już kilkadziesiąt lat temu Kodeksu dyplomatycznego Kujaw i ziemi dobrzyńskiej ${ }^{1}$ światła dziennego dotąd nie ujrzał nawet pierwszy tom. Badaczom przychodzi zatem korzystać ze starych i niepełnych pod względem wykorzystania podstawy źródłowej publikacji wydanych przez Leona Rzyszczewskiego i Antoniego Muczkowskiego ${ }^{2}$ oraz Bolesława Ulanowskiego ${ }^{3}$. Nadto dokumenty kujawskie sa rozproszone w wielu innych wydawnictwach źródłowych ${ }^{4}$. Tymczasem zachowane zbiory archiwalne, nawet jeśli weźmiemy pod uwagę wyłącznie oryginalne dokumenty dotyczące bezpośrednio Kujaw i ziemi dobrzyńskiej, wydają się dość obfite. Oferuja przy tym nie tylko dotąd nieopublikowane dokumenty piętnastowieczne, ale także czternastowieczne. Wydaje się zatem zasadne ich publikowanie osobno, zwłaszcza starszych źródeł wspomnianego wyżej typu.

Szczególnie zasobny w nieopublikowane dokumenty czternastowieczne jest przechowywany w Archiwum Państwowym w Bydgoszczy

1 Zob. J. Bieniak, Prace nad Kodeksem dyplomatycznym Kujaw i ziemi dobrzyńskiej w Toruniu, ZH 1975, t. XL, z. 1, s. 179.

$2 \mathrm{KDP}, \mathrm{t} . \mathrm{II} / 2$.

3 DKM.

4 Przykładowo: CDMG; KDW; P; PrUB. 
zespół archiwalny dawnego klasztoru cystersów w Koronowie (Byszewie) $^{5}$. Dwa spośród nich zamieszczamy w niniejszym tekście.

Pierwszym z nich jest dokument, który wystawił 25 listopada $1358 \mathrm{r}$. „kasztelan w Bydgoszczy” Mściwoj („Myscziwus”) ${ }^{6}$. Urzędnik ów poświadczył w nim ugodę zawartą przez opata byszewskiego (koronowskiego) Jana II (sprawował tę funkcję w latach 1352-1354) i sołtysa należącej do tamtejszych cystersów wsi Włóki Stefana z Wojciecha, wdową po poprzednim sołtysie Mikołaju oraz jej dziećmi Janem i Anną ${ }^{7}$. Na jej mocy wdowa wraz z dziećmi za 7 grzywien zrezygnowała z wszelkich pretensji do włóckiego sołectwa. Wprawdzie Ryszard Kozłowski uważał, że chodziło tu o zwykłą sprzedaż sołectwa ${ }^{8}$, jednak bardziej prawdopodobne jest inne rozwiązanie tego problemu. Za kluczowe należy uznać znajdujące się w dokumencie stwierdzenie, że wdowa wraz z dziećmi zrzekła się go za wspomnianą wyżej sumę na podstawie „amicabilis composicionis", która zawarła z opatem i obecnym sołtysem. Wydaje się zatem, że wobec śmierci poprzedniego sołtysa i niepełnoletniości jego spadkobierców Jan II, jako właściciel Włók, najpierw wyznaczył nowego sołtysa, a następnie wymusił na spadkobiercach pozbycie się ich dziedzicznej własności. Opatowi nie należy się przy tym dziwić, cystersi mieli bowiem problemy z zarządem sołeckim nad Włókami już wcześniej. Jak ustalił R. Kozłowski, już w 1345 r. opat byszewski (koronowski) Piotr I odebrał mieszczanom chełmińskim włóckie sołectwo, ponieważ ich zaniedbania doprowadziły do upadku gospodarczego

5 AP w Bydgoszczy, Koronowo Kl. 6-437 (dawniej Koronowo Kl. A.). O klasztorze cystersów założonym pierwotnie w Byszewie, a przeniesionym następnie do wsi Smeysche, na której miejscu zostało lokowane miasto Koronowo zob. R. Kozłowski, Mikołaj - fundator klasztoru cysterskiego w Byszewie, „Prace Komisji Historii Bydgoskiego Towarzystwa Naukowego" 1970, t. VII, s. 4152; idem, Rozwój uposażenia klasztoru cysterskiego w Byszewie (Koronowie) do końca XIV w., Warszawa-Poznań 1972; F. Sikora, Upadek fundacji cysterskiej $w$ Szpetalu i poczatki odnowionego klasztoru byszewskiego, ZH 1975, t. LX, z. 2, s. 7-25; B. Śliwiński, Pogranicze kujawsko-pomorskie w XII-XIII wieku. Z dziejów Bydgoskiego $i$ Wyszogrodzkiego w latach 1113-1296, Warszawa-Poznań 1989, s. 27-31, 74-83; E. Okoń, P. Oliński, Byszewo-Koronowo [w:] Monasticon Cisterciense Poloniae, red. A.M. Wyrwa, J. Strzelczyk, K. Kaczmarek, t. 2, Poznań 1999, s. 42-43 oraz artykuły stanowiące pokłosie konferencji naukowej, która odbyła się w Koronowie w 2000 r. z okazji 750-lecia fundacji opactwa, zob. Opactwo w Byszewie-Koronowie na tle działalności kulturowej cystersów na Kujawach i Pomorzu Wschodnim, „Nasza Przeszłość” 2001, t. XCVI, s. 11-193.

6 Zob. dokument 1.

7 Series abbatum coenobii Byszoviensis seu Coronoviensis, wyd. W. Kętrzyński [w:] MPH, t. V, Lwów 1887, s. 5.

$8 \quad$ R. Kozłowski, Rozwój..., s. 238. 
wsi ${ }^{9}$. Zapewne to właśnie dopiero wówczas cystersi zaczęli porządkować w niej stosunki. Być może po 1345 r. sołectwo otrzymał wtedy od nich Mikołaj, mąż Wojciechy, który zmarł przed 1358 r. Po jego śmierci opat Jan II, mając niewątpliwie w pamięci dawne kłopoty z mieszczanami chełmińskimi, szybko wyznaczył nowego sołtysa i doprowadził do rezygnacji z uprawień do sołectwa przez Wojciechę i jej dzieci, co zostało potwierdzone przez publikowany tu dokument.

Eschatokół dokumentu „kasztelana w Bydgoszczy” Mściwoja z 1359 r. jest, niestety, pozbawiony miejsca wystawienia. Wziąwszy jednak pod uwagę „urzędowe” powiązanie jego wystawcy z Bydgoszcza, można przypuszczać, że interesujace nas źródło zostało przezeń wystawione właśnie w tym ośrodku. W eschatokole nie uwzględniono również testacji.

Wystawcę interesującego nas dokumentu już Janusz Bieniak zidentyfikował z Mściwojem, bratem starosty kujawskiego Przedbora z Koniecpola h. Pobóg ${ }^{10}$. Mściwoj od 1349 r. występował jako burgrabia w Bydgoszczy, niewątpliwie z ramienia swego brata zarządzającego podówczas całymi Kujawami znajdującymi się pod bezpośrednią władzą króla Kazimierza Wielkiego. Ten sam Mściwoj w dokumencie królewskim z 19 lutego 1353 r. wystawionym w Inowrocławiu wystapił w liście świadków jako „castellanus Bidgostiensis” ${ }^{11}$. Jako „castellanus in Bydgosczia” został również określony we własnym dokumencie, który tu publikujemy. Wspomniany wyżej badacz pierwotnie uznał, że „tytuły kasztelana i burgrabiego czasem mylono, jest więc dość wątpliwe, czy Mściwój, przeszedł z administracji starościńskiej do hierarchii ziemskiej”. Dodatkowo zaś stwierdził, że treść wystawionego w $1358 \mathrm{r}$. dokumentu „wskazuje na pełnienie przezeń [tj. Mściwoja przyp. S.Sz.] nadal funkcji burgrabiego"12. Ostatnio jednak pogląd J. Bieniaka dotyczący kwalifikacji urzędu sprawowanego przez Mściwoja na północnych Kujawach w latach 1353-1358 uległ zmianie, ponieważ bez bliższego uzasadnienia uznał go za kasztelana bydgoskiego, czyli urzędnika ziemskiego ${ }^{13}$.

$9 \quad$ PrUB, Bd. III, nr 714a; R. Kozłowski, Rozwój..., s. 238; ostateczne zrzeczenie się praw do sołectwa przez spadkobierców pierwotnych sołtysów wywodzących się z Chełmna nastapiło dopiero w 1368 r., zob. ibidem.

10 J. Bieniak, Przedbor z Koniecpola [w:] PSB, t. XXVIII, Wrocław 1985, s. 700.

11 KDP, t. II/2, nr 505.

12 J. Bieniak, Przedbor z Koniecpola..., s. 700.

13 Urzędnicy kujawscy i dobrzyńscy XII-XV wieku. Spisy [dalej: Urz. kuj.-dobrz.], oprac. J. Bieniak, S. Szybkowski, Kórnik 2014, s. 76, 174. 
Z poglądem tym nie można się jednak zgodzić. Przeciwko uznaniu Mściwoja za urzędnika ziemskiego przemawia bowiem bardzo ważna przesłanka. Oto bowiem jako przedstawiciel rodu Pobogów nie spełniał on wymogu kujawskiej osiadłości ${ }^{14}$, niezbędnej do otrzymania od króla nominacji na urząd ziemski w którejkolwiek z tamtejszych hierarchii ziemskiej. Wszyscy czternastowieczni kasztelanowie bydgoscy poza nim, zestawieni w spisach urzędniczych, byli bowiem z cała pewnością kujawskimi terrigenami ${ }^{15}$. Przeciwko uznaniu Mściwoja za urzędnika ziemskiego przemawia dodatkowo, podnoszony wprawdzie przez J. Bieniaka, lecz później przezeń zapomniany, fakt bardzo częstego zamiennego stosowania w polskich czternastowiecznych źródłach terminu „castellanus” w charakterze określenia burgrabiów jako urzędników administracji starościńskiej, co znakomicie uzasadnił Antoni Gasiorowski ${ }^{16}$. Nie inaczej było także w nieco późniejszym okresie na Kujawach, gdy we własnym dokumencie z 1374 r. burgrabia ówczesnego starosty inowrocławsko-gniewkowskiego Sędziwoja z Szubina, stolnik poznański Gerward ze Słomowa, przedstawiał się jako: „burgravius seu castellanus Gnevcoviensis et Juvenis Vladislaviensis"17. Dokument burgrabiego Gerwarda ze względu na jego range (potwierdzenie darowizny mieszczanina inowrocławskiego dla tamtejszego klasztoru franciszkanów) również zdaje się potwierdzać, że czternastowieczni burgrabiowie kujawscy mogli

14 Posiadłości przedstawicieli rodu Pobogów na terenie Kujaw nie notują współczesne badania dotyczące własności rycerskiej na średniowiecznych Kujawach oraz stosunków majątkowych najbliższego kręgu rodzinnego Mściwoja i jego brata Przedbora z Koniecpola, zob. B. Śliwiński, Pogranicze kujawsko-pomorskie..., s. 9-69; idem, Problem granicznego charakteru Wisty w dziejach Kujaw i Mazowsza do końca XII w. na tle stosunków własnościowo-osadniczych [w:] Osadnictwo nad Dolnq Wista w średniowieczu, red. S. Gierszewski, Warszawa 1989, s. 37-49; idem, Rozwój własności rycerskiej w południowej części Kujaw Inowrocławskich w XII-XIII wieku, „Ziemia Kujawska" 1993, t. IX, s. 45-75; A. Szymczakowa, Szlachta sieradzka w XV wieku: „Magnifici et generosi”, Łódź 1998, s. 29-62; eadem, „Nobiles Siradienses”. Rody Porajów, Pomianów, Gryfów, Kopaczów i Pobogów, Warszawa 2011, s. 433-477. O wymogu osiadłości jako kwalifikacji koniecznej do uzyskania nominacji na urzędnika ziemskiego w konkretnej hierarchii zob. A. Gasiorowski, Urzędnicy zarzqdu lokalnego w późnośredniowiecznej Wielkopolsce, Poznań 1970, s. 97; A. Szymczakowa, Urzędnicy łęczyccy i sieradzcy do połowy XV wieku, Łódź 1984, s. 55-57; S. Szybkowski, Kujawska szlachta urzędnicza w późnym średniowieczu (1370-1501), Gdańsk 2006, s. 125.

15 Urz. kuj.-dobrz., s. 75-77.

16 A. Gasiorowski, „Castellanus”. Przyczynek semazjologiczny, „Slavia Antiqua” 1971, t. XVIII, s. 212-215.

17 D. Karczewski, Franciszkanie $w$ monarchii Piastów $i$ Jagiellonów $w$ średniowieczu. Powstanie - rozwój-organizacja wewnętrzna, Kraków 2013, s. 165, przyp. 68. 
wystawiać dokumenty dotyczące mniej ważnych spraw związanych z zarządem starościńskim. Podobną wagę ma dokument Mściwoja, co stanowi dodatkową przesłankę za uznaniem go za urzędnika administracji starościńskiej, a nie urzędnika ziemskiego ${ }^{18}$.

Natomiast za słuszne należy uznać przypuszczenie A. Szymczakowej, która zidentyfikowała burgrabiego bydgoskiego z lat 1349-1358 Mściwoja z Mściwojem ze Strońska ${ }^{19}$, sprawujacym w latach 1360-1377 urząd kasztelana rudzkiego ${ }^{20}$. Nominacja na urząd kasztelana rudzkiego stanowiła zapewne dla Mściwoja rekompensatę za to, że musiał opuścić burgrabiostwo bydgoskie (jego poprzednik na kasztelanii rudzkiej po raz ostatni z odnośna tytulatura pojawił się 14 lutego 1359 r.). Było to związane z nadaniem przez Kazimierza Wielkiego w 1359 r. w lenno ziemi inowrocławskiej księciu gniewkowskiemu Władysławowi Białemu. Doprowadziło to do tego, że ziemia bydgoska utraciła łączność terytorialną z Kujawami Brzeskimi nadal zarządzanymi przez Mściwojowego brata Przedbora z Koniecpola. Skutkiem tej królewskiej decyzji było powołanie osobnego starostwa bydgoskiego, w którym jego zarządca powołał swój własny aparat starościński, pozbywając się nominatów poprzednika ${ }^{21}$. Najwyraźniej wówczas dziedzic Strońska powrócił do rodzinnej ziemi, kontentując się sprawowaniem urzędu kasztelana rudzkiego. Zgodnie z ustaleniami A. Szymczakowej Mściwoj był protoplastą sieradzkiej rodziny szlacheckiej Zapolskich h. Pobóg, dziedziczących także w Strońsku, Barczewie i Chojnem ${ }^{22}$.

18 Tak zresztą wcześniej uważał J. Bieniak, zob. idem, Przedbór z Koniecpola..., s. 700.

19 Urzędnicy tęczyccy, sieradzcy i wieluńscy XIII-XV wieku. Spisy [dalej: Urz. łęcz.-sier.], oprac. J. Bieniak, A. Szymczakowa, Wrocław 1985, s. 148-149, 186; Urz. kuj.-dobrz., s. 76, 174; A. Szymczakowa, „Nobiles Siradienses”..., s. 457.

20 Urz. łęcz.-sier., s. 148-149. Jako terrigena sieradzki spełniał przy tym wymóg osiadłości, ponieważ w składającym sie z dwóch ziem, sieradzkiej i wieluńskiej, późnośredniowiecznym województwie sieradzkim obowiązywał najwyraźniej „ogólnosieradzki” wymóg osiadłości, którego spełnienie pozwalało pełnić również urzędy w ziemskiej hierarchii wieluńskiej - większość kasztelanów rudzkich (wieluńskich) w XIV-XV w. było ziemianami sieradzkimi, zob. ibidem, s. 149-150. Podobnie było na Kujawach (podzielonych wszak na dwa województwa: brzeskie i inowrocławskie), gdzie wystarczyła „ogólnokujawska" osiadłość, aby uzyskać nominacje w dowolnej hierarchii ziemskiej tej dzielnicy, zob. S. Szybkowski, Kujawska szlachta urzędnicza..., s. 125.

21 Urz. kuj.-dobr., s. 133, 137; J. Bieniak, Przedbor z Koniecpola..., s. 699.

22 Nieznana z imienia wdowa po nim, kasztelanowa rudzka, żyła jeszcze w $1392 \mathrm{r}$. Dziećmi Mściwoja byli zaś: Stanisław i Mikołaj oraz nieznana z imienia żona kasztelanica łęczyckiego Tomasza z Nowogrodu h. Doliwa, zob. A. Szymczakowa, Szlachta sieradzka..., s. 457-458, 463-464. 
Do jego curriculum vitae należy jeszcze dodać fakt dzierżenia w 1361 r. zarządu nad zamkiem arcybiskupim w Łowiczu („Msczuyus de Saronsko, qui tunc castrum Lovicense regebat et tenebat"), a zapewne także nad tamtejszym kluczem dóbr arcybiskupstwa. Wyznaczenie mu tej funkcji przez ówczesnego arcybiskupa Jarosława Bogorię ze Skotnik przekonuje, że Mściwoj posiadał spore doświadczenie administracyjne. Uważamy to za kolejny argument przemawiający za tym, że w latach 1349-1358 był burgrabią bydgoskim z ramienia swojego brata - starosty kujawskiego, a nie urzędnikiem ziemskim - kasztelanem bydgoskim ${ }^{23}$.

Drugim publikowanym tu źródłem jest wystawiony 8 lutego 1368 r. w Bydgoszczy dokument podkomorzego krakowskiego i starosty bydgoskiego Mściwoja z Kwiliny h. Lis ${ }^{24}$. Wystawca poświadczył, że na polecenie króla Kazimierza Wielkiego dokonał rozgraniczenia pomiędzy wsią Knieja, stanowiącą własność opata byszewskiego (koronowskiego) Jana III (sprawował urząd w latach 1365-139025), a Żołędowem, należącym do braci Jana, Wojciecha, Jarosława i Przedpełka ze Służewa. Obie spośród wymienionych tu wsi były położone w północnej części ówczesnego powiatu bydgoskiego, w pobliżu Koronowa stanowiącego siedzibę i ośrodek klucza dóbr należących do klasztoru byszewskiego (koronowskiego). O ile jednak Żołędowo istnieje do dzisiaj, to Knieja (będąca faktycznie przysiółkiem cysterskiego Tryszczyna) nie przetrwała do chwili obecnejé. Partnerami opata Jana III w przeprowadzeniu operacji rozgraniczenia byli przedstawiciele znaczacej linii rodu Pomianów, wywodzącej się ze Służewa w ziemi gniewkowskiej. Ich ojcem według ustaleń Joanny Karczewskiej był podczaszy brzeski w 1349 r. Przedpełk ze Służewa ${ }^{27}$. Prawie wszyscy występujący w publikowanym tu dokumencie synowie podczaszego również sprawowali urzędy ziemskie: Jan (Jasiek) Bogatka był najpierw podkonim brzeskim (1362), następnie zaś podkomorzym gniewkowskim (inowrocławskim)

23 Nowy kodeks dyplomatyczny Mazowsza, cz. III: Dokumenty z lat 1356-1381, wyd. I. Sułkowska-Kuraś, S. Kuraś, Warszawa 2000, nr 56; Urz. łęcz.-sier., s. 186; Ł. Włodarski, Dwór i najbliższe otoczenie arcybiskupa gnieźnieńskiego Jarosława Bogorii ze Skotnik, „Studia z Dziejów Średniowiecza” 2015, t. 19, s. 243, 255.

${ }_{24}$ Zob. dokument 2.

25 Series abbatum..., s. 5.

26 R. Kozłowski, Rozwój..., s. 207-208, 231-232.

27 Urz. kuj.-dobrz., s. 55, 174; J. Karczewska, Ród Pomianów na Kujawach w średniowieczu, Poznań-Wrocław 2003, s. 25-27. 
$(1368)^{28}$, Wojciech podczaszym brzeskim (1368-1377) ${ }^{29}$, Jarosław zaś chorążym inowrocławskim (gniewkowskim) 1384-1404 ${ }^{30}$. Jedynie żyjący do 1404 r. Przedpełk Przedpełkowic ze Służewa nigdy nie uzyskał promocji na urząd ziemski ${ }^{31}$.

Wystawca dokumentu, Mściwoj z Kwiliny h. Lis, to osoba, której curriculum vitae jest bardzo dobrze znane współczesnej polskiej historiografii. Wywodził się on z wybitnej małopolskiej rodziny możnowładczej mającej także związki majątkowe z Górnym Śląskiem. Z rąk Kazimierza Wielkiego, którego był bliskim współpracownikiem, najpierw otrzymał urząd łowczego krakowskiego 1347-1363, a następnie tamtejszego podkomorzego (1363-1382). Był również pierwszym ze znanych starostów bydgoskich (1362-1368) ${ }^{32}$. Mściwoj mógł otrzymać na ten urząd nominację już około 1359/1360 r., kiedy, jak sugerowaliśmy wyżej, burgrabiostwo bydgoskie utracił Mściwoj ze Strońska sprawujący je z ramienia Przedbora z Koniecpola, który wówczas przestał zarządzać ziemią bydgoską. Dokument z 8 lutego 1368 r. jest ostatnim źródłem poświadczającym Mściwoja z Kwiliny na urzędzie starosty bydgoskiego. Nie można jednak wykluczyć, że zarząd nad starostwem bydgoskim sprawował nadal, aż do chwili śmierci króla Kazimierza Wielkiego w 1370 r. i przejścia ziemi bydgoskiej w charakterze lenna Królestwa w posiadanie wnuka wspomnianego władcy, księcia Kazimierza Bogusławica (Kaźka). Pozytywne zweryfikowanie tego przypuszczenia nie jest jednak możliwe, ponieważ Mściwoj po 1368 r. jest znany wyłącznie ze źródeł małopolskich, w których także i wcześniej nie stosowano w stosunku do niego tytulatury starosty bydgoskiego ${ }^{33}$.

28 Urz. kuj.-dobrz., s. 59, 83, 173; J. Karczewska, Ród Pomianów..., s. 26-28; S. Szybkowski, Kujawska szlachta urzędnicza..., s. 552-553.

29 Urz. kuj.-dobrz., s. 174; J. Karczewska, Ród Pomianów..., s. 27-29; S. Szybkowski, Kujawska szlachta urzędnicza..., s. 711-712.

30 Urz. kuj.-dobrz., s. 45-46, 93, 171 (tu nietrafnie jego urząd, rzekome chorąstwo brzeskie, przypisane późniejszemu sędziemu inowrocławskiemu Jarosławowi z Sadlna, a jednolita kadencja chorążego inowrocławskiego [gniewkowskiego] podzielona na dwie odrębne kadencje: gniewkowską 1399 r. i inowrocławską 1402-1404); J. Karczewska, Ród Pomianów..., s. 29-30; S. Szybkowski, Kujawska szlachta urzędnicza..., s. 464-465, 583-585 (tu uzasadnienie jednolitej kadencji Jarosława jako chorążego inowrocławskiego [gniewkowskiego] w latach 1384-1404).

31 J. Karczewska, Ród Pomianów..., s. 26-27, 29, 76-77, 79, 86-87.

32 Urz. mp., s. 76, 91, 331; Urz. kuj.-dobrz., s. 137, 165; B. Wyrozumska, Mściwoj z Kwiliny [w:] PSB, t. 22, Wrocław 1977, s. 233-234; B. Śliwiński, Lisowie Krzelowscy w XIV-XVw. i ich antenaci. Studium genealogiczne, Gdańsk 1993, s. 31-37.

33 Urz. kuj.-dobrz., s. 137. 
W przeciwieństwie do pierwszego z publikowanych tu źródeł dokument Mściwoja z Kwiliny zawiera listę świadków. Na pierwszym miejscu wśród nich znalazł się przyrodni brat wystawcy, niepełniący urzędów, Mikołaj z Krzelowa, notowany w źródłach w latach 1359-1381 ${ }^{34}$. Kolejni świadkowie to już mieszkańcy ziemi bydgoskiej - a nawet bliscy sąsiedzi zarówno cystersów byszewskich (koronowskich), jak i dziedziców z Żołędowa - Budek z Wierzchucinka, Marcin z Nekli i Jarosław z Jastrzębi. Można nawet przypuszczać, wziąwszy pod uwagę ich osiadłość, że brali udział w rozgraniczeniu Kniei i Żołędowa, w przeciwieństwie bowiem do wywodzącego się z Małopolski starosty dysponowali szczegółową wiedzą dotycząca granic wspomnianych wsi.

Spośród świadków Marcin i Jarosław, to homines unius facti ${ }^{35}$. Jedynie w przypadku Jarosława można ostrożnie przypuszczać, że łączyły go jakieś związki rodzinne (agnatyczne lub kognatyczne) $\mathrm{z}$ właścicielami Żołędowa ${ }^{36}$. Za tym przypuszczeniem zdaje się bowiem przemawiać jego imię (agnatyczne w rodzie Pomianów) oraz bezpośrednie sąsiadowanie Jastrzębi z Żołędowem, co sprawia wrażenie, ze obie wsie stanowiły pierwotnie część jednego kompleksu majątkowego, później podzielonego. Więcej wiemy na temat kolejnego świadka: Budka z Wierzchucinka. Był związany ze starostą Mściwojem, z jego ramienia bowiem w 1364 r. pełnił urząd burgrabiego bydgoskiego, najwyraźniej jednak także później pozostawał w jego otoczeniu. Po odejściu dziedzica Kwiliny z urzędu starościńskiego oraz śmierci króla Kazimierza Wielkiego Budek związał się z władającym ziemią bydgoską księciem Kazimierzem Bogusławicem (Kaźkiem), co źródła odnotowywały w latach 1374-1375 ${ }^{37}$.

Ostatnią osobą odnotowaną w eschatokole dokumentu starosty Mściwoja z Kwiliny jest jego pisarz, ksiądz Leonard, ujęty w formule per manus.

34 B. Śliwiński, Lisowie Krzelowscy..., s. 39-41.

35 J. Karczewska, Własność szlachecka na pograniczu wielkopolsko-kujawskim w pierwszej połowie XV wieku, Kraków 2010, s. 300.

36 Kolejny właściciel Jastrzębi, Mikołaj, znany jest dopiero ze źródła z 1409 r., do wystawionego wówczas dokumentu przywiesił pieczęć z herbem Rola, zob. ibidem. Nie wiemy jednak, czy był spokrewniony (i w jakim stopniu) z Jarosławem, mógł być zarówno jego agnatem, jak i kognatem, a nawet osobą niespokrewniona, która nabyła posiadłość w Jastrzębi od spadkobierców Jarosława w wyniku kupna lub zamiany.

37 S. Szybkowski, Rzqdy Kazimierza (Kaźka) Bogusławica w ziemi bydgoskiej. Jeszcze o otoczeniu księcia słupsko-bydgosko-dobrzyńskiego, „Gdańskie Studia z Dziejów Średniowiecza” 1999, t. VI, s. 253; J. Karczewska, Wtasność szlachecka..., s. 299. 


\section{Dokument 1}

$$
\text { [b.m., Bydgoszcz?], } 25 \text { XI } 1358
$$

Burgrabia bydgoski Mściwoj [ze Strońska] poświadcza, że opat klasztoru cysterskiego w Byszewie (Koronowie) Jan [II] i sołtys wsi klasztornej Włóki Stefan zawarli ugodę w sprawie sporu o sołectwo we Włókach z Wojciecha, wdowa po zmartym sottysie wspomnianej wsi Mikołaju, oraz jej dziećmi Janem i Annq. Za siedem grzywien Wojciecha $i$ jej dzieci zrezygnowali z wszelkich roszczeń do sołectwa.

Oryg.: AP w Bydgoszczy, Koronowo Kl. 6-437-88 (dawniej Koronowo Kl. A. 88), perg. $215 \times 115+32$, pod dokumentem przywieszona słabo zachowana pieczęć wystawcy, zob. M. Hlebionek, Katalog pieczęci przy dokumentach samoistnych w zasobie Archiwum Państwowego w Bydgoszczy, Warszawa 2012, nr 295.

Uwaga: Tekst źródta wydany wedtug zasad zawartych w A. Wolff, Projekt instrukcji wydawniczej dla pisanych źródet historycznych do połowy XVI wieku, SŹ, t. I, 1957.

Nos Myscziwus castellanus in Bydgosczia ${ }^{1}$ universis et singulis Christifidelibus serie presencium declaramus $\mid$ in verbo veritatis publice protestantes, quod vir religiosus dominus Johannes abbas de Byssovia | Ordinis Cystersiensis $[s]^{2}$ et Stephanus scultetus de hereditate dicti domini abbatis et sui monasterii Vloky ${ }^{3}$ vulgariter nuncupata cum Woyczecha, relicta quidam Nycolai sculteti ibidem ${ }^{4}$, suisque legitimis heredibus, videlicet Johanne et Anna ${ }^{5}$, pro impeticione prefate scultecie amicabilem facientes composicionem, ipsis dederunt VII marcas denariorum et ad eandem composicionem ratihabendam eadem Woyczecha ac dicti sui filii [s] omnisque eorum amici sponte omnino abrenunciaverunt impeticioni omnique juri, que eis in predicta scultecia competere videbatur. In cuius rei evidenciam sigillum nostrum in testimonium perpetue ordinacionis presentibus est appensum. Datum anno Domini millesimo CCCLVIII in die beate Katherine gloriosissime Virginis et Martiris.

1 Mściwoj ze Strońska h. Pobóg, brat starosty kujawskiego Przedbora z Koniecpola, burgrabia bydgoski z jego ramienia 1349-1358, kasztelan rudzki 1360-1377 (Urz. tęcz.-sier., s. 148, 149, 186). 
${ }^{2}$ Opat byszewski (koronowski) Jan II 1352-1364 (Series abbatum..., s. 5).

3 Sottys we Wtókach Stefan, niezidentyfikowany.

${ }^{4}$ Wojciecha $i$ jej zmarty mąż Mikołaj, niezidentyfikowani.

${ }^{5}$ Jan i Anna, dzieci Mikołaja i Wojciechy, niezidentyfikowani.

Dokument 2

Bydgoszcz, 8 II 1368

Podkomorzy krakowski $i$ starosta bydgoski Mściwoj [z Kwiliny] poświadcza, że z upoważnienia króla Kazimierza [Wielkiego] dokonat rozgraniczenia pomiędzy wsia Knieja, należącą do opata klasztoru cysterskiego w Byszewie (Koronowie) Jana [III] i jego konwentu, a wsia Żotędowo, należaca do braci ze Stużewa: podkomorzego gniewkowskiego (inowrocławskiego) Jaśka [Jana], podczaszego brzeskiego Wojciecha, Jarostawa i Przedpetka.

Oryg.: AP w Bydgoszczy, Koronowo Kl. 6-437-102 (dawniej Koronowo Kl. A. 102), perg. 370x155+40, pasek pergaminowy po niezachowanej pieczęci wystawcy.

Uwaga: Tekst źródła wydany wedtug zasad zawartych w A. Wolff, Projekt instrukcji wydawniczej dla pisanych źródet historycznych do połowy XVI wieku, SŹ, t. I, 1957.

a|Ulniversis Christifidelibus, ad quos presentes pervenerint, blnlos Mscziwogius capitaneus Bydgostiensis nec non subcamerarius Cracoviensis ${ }^{1}$ presentibus prestamur et hoc illibata permanent ac rolbur pepetue firmitatis obtineant serie presencium publice manifestamus, quomodo ex commissione incliti serenissimique principis, domini Kazimiri regis Polonie, inter fratrem | Johannem abbatem monasterii Bysoviensis ${ }^{2}$ et conventum ibidem et dominos ac nobiles viros heredes de Sluzewo ${ }^{3}$ et de Solandowo ${ }^{4}$, videlicet Jesconem subcamerarium $\mid$ Gnewcoviensem ${ }^{5}$, Albertum subpincernam Brestensem ${ }^{6}$, Jaroslaum ${ }^{7}$, Psredpolkonem ${ }^{8}$ utraque parte consenciente, talem inter hereditatem Knyeye ${ }^{9}$ cenobii predicti Byssoviensis et Solandowo herediatatem prefatorum heredum dominorumque de Sluzewo, fecimus limitacionem ac unionem perpetuam de voluntate utriusque partis, videlicet absque nullo preiudicio, impedimento seu gravamine antiqui privilegii dicti claustri super hereditatem Triscznicza ${ }^{10}$, Kneya ex antiquo nominatam, que hereditas est sita inter rivulos Kothomirznicza ${ }^{11}$ et Lochotnicza ${ }^{12}$, 
de quo rivulo Lochotnicza ad nostram peticionem et induccionem dominus abbas cessit usque ad quercum ex utraque parte circa via signatum absque preiudicio et impedimento antiqui privilegii, ut promittitur taliter vero, quot limitacio ambarum hereditatum Solandowo et Knyeya ac Thrisnicza incipit a rivulo Kothomirznicza in via, quia transit de Mocre ${ }^{13}$ in Nemcz ${ }^{14}$, ubi gades ex utraque vie sunt manifeste distincte, usque ad unum quercum ex utraque parte similiter signatum, deinde directe descendendo per borram, usque ad fluvium Dbra $^{15}$ et ad medium fluvii ad tres lapides ibidem iacentes, ubi limitacio dictorum hereditatum terminatur. In cuius rei perpetuam firmitatem et evidenciam ampliorem sigillum nostrum presentibus est appensum. Datum in Bydgosczia sub feria quarta post Circumdederunt me sub anno Domini milesimo [s] CCCLXVIII. Presentibus hiis testibus: Niczkone herede de Chrzelowo ${ }^{16}$, Budkone herede de Wirchoczino $^{17}$, Martino herede de Nakla ${ }^{18}$, Jaroslao herede de Jastrabe ${ }^{19}$ et aliis plurimis fidedignis. Data vero per manus Laurencii presbiteri et notarii ${ }^{20}$.

a Inicjat wysokości dwóch wersów kolumny tekstu.

b Inicjat wysokości trzech wersów kolumny tekstu.

1 Mściwoj z Kwiliny h. Lis, łowczy krakowski 1347-1363, podkomorzy krakowski 1363-1382, starosta bydgoski 1362-1368 (Urz. mp., s. 76, 91, 331; Urz. kuj.-dobrz., s. 137, 165; B. Wyrozumska, Mściwoj z Kwiliny..., s. 233-234; B. Śliwiński, Lisowie Krzelowscy..., s. 31-37).

2 Opat byszewski (koronowski) Jan III 1365-1390 (Series abbatum..., s. 5).

3 Stużewo, dawniej miasto prywatne, obecnie wieś, gmina Aleksandrów Kujawski, powiat aleksandrowski, województwo kujawsko-pomorskie.

4 Żołędowo, wieś, obecnie gmina Osielsko, powiat bydgoski, województwo kujawsko-pomorskie.

5 Jan (Jasiek) Bogatka ze Stużewa h. Pomian, podkoni brzeski 1362, podkomorzy inowrocławski (gniewkowski) 1368 (Urz. kuj.-dobrz., s. 59, 83, 173; J. Karczewska, Ród Pomianów..., s. 26-28; S. Szybkowski, Kujawska szlachta urzędnicza..., s. 552-553).

${ }^{6}$ Wojciech ze Stużewa i Lutoborza h. Pomian, podczaszy brzeski 1368-1377 (Urz. kuj.-dobrz., s. 174; J. Karczewska, Ród Pomianów..., s. 27-29; S. Szybkowski, Kujawska szlachta urzędnicza..., s. 711-712).

7 Jarosław z Przybranowa h. Pomian, choraży inowrocławski (gniewkowski) 1384-1404 (Urz. kuj.-dobrz, s. 93, 171; J. Karczewska, Ród Pomianów, s. 29-30; S. Szybkowski, Kujawska szlachta urzędnicza, s. 464-465, 583-585).

8 Przedpetk ze Stużewa h. Pomian, wyst. 1368-1404 (J. Karczewska, Ród Pomianów..., s. 26, 27, 29, 76-77, 79, 86-87).

${ }^{9}$ Knieja, nieistniejacy obecnie przysiótek Tryszczyna (R. Kozłowski, Rozwój..., s. 208).

10 Tryszczyn, wieś, obecnie gmina Koronowo, powiat bydgoski, województwo kujawsko-pomorskie. 
11 Kotomierzyca (Kotomierzanka), rzeka, lewy doptyw Brdy.

12 Łokietnica, rzeka, dawniej lewy dopływ Brdy, uchodzący do niej poniżej ujścia Kotomierzycy.

${ }_{13}$ Mokre, nieistniejaca obecnie wieś, położona w historycznym powiecie bydgoskim, od 1520 r. własność klasztoru koronowskiego (byszewskiego) (Z. Guldon, Rozmieszczenie własności na Kujawach w II połowie XVI w., Toruń 1964, s. 84; R. Kozłowski, Rozwój, s. 208).

${ }_{14}$ Niemcz, wieś, obecnie gmina Osielsko, powiat bydgoski, województwo kujawsko-pomorskie.

15 Brda, rzeka, lewy doptyw Wisty.

${ }^{16}$ Mikołaj z Krzelowa h. Lis, brat przyrodni starosty Mściwoja, wyst. 1359-1381 (B. Śliwiński, Lisowie Krzelowscy..., s. 39-41).

17 Budek $z$ Wierzchucinka (wieś położona w historycznym powiecie bydgoskim, obecnie gmina Sicienko, powiat bydgoski, województwo kujawsko-pomorskie), wyst. 1364-1375, burgrabia bydgoski z ramienia starosty Mściwoja z Kwiliny 1364 (S. Szybkowski, Rzady Kazimierza..., s. 253; J. Karczewska, Wtasność szlachecka..., s. 299).

18 Marcin $z$ Nekli (wieś $w$ historycznym powiecie bydgoskim, położona $w$ pobliżu Żołędowa, obecnie gmina Osielsko, powiat bydgoski, województwo kujawsko-pomorskie), znany tylko z tego wystapienia (J. Karczewska, Wtasność..., s. 300).

19 Jarosław z Jastrzębi (wieś w historycznym powiecie bydgoskim, położona w poblizu Żołędowa, obecnie gmina Osielsko, powiat bydgoski, województwo kujawsko-pomorskie), znany tylko z tego wystapienia (J. Karczewska, Wtasność szlachecka..., s. 300).

${ }^{20}$ Ksiqdz Leonard, pisarz starosty Mściwoja z Kwiliny.

\section{Abstract \\ Two Unprinted $14^{\text {th }}$-Century Documents from Byszewo (Koronowo)}

The subject of this study are two hitherto unprinted $14^{\text {th }}$-century documents from the collection of the National Archive in Bydgoszcz, from the original parchment documents of the Cistercian monastery in Byszewo (Koronowo). The first one is the document issued on November 25, 1358, possibly in Bydgoszcz, by the Burgrave of Bydgoszcz, Mściwoj from Strońsko, in which he attested that the abbot of the Cistercian monastery in Byszewo (Koronowo), Jan II, and the soltys of the monastery village Włóki, Stefan, came into an agreement regarding the dispute over the sołectwo in Włóki with Wojciecha, widow of the late Mikołaj, sołtys of the mentioned village, and her children Jan and Anna, who for 7 grzywnas gave up any claims for the solectwo.

The second document was issued in Bydgoszcz on February 8, 1368, by the Chamberlain of Cracow and Starost of Bydgszcz, Mściwoj from Kwilina, who attested that on behalf of king Casimir the Great he established a boundary line between the village of Knieja, belonging to the abbot of the Cistercian monastery in Byszewo (Koronowo), Jan III, and 
his convent, and the village of Żołędowo, belonging to the brothers from Służewo: Jan, Wojciech, Jarosław, and Przedpełk. Both documents have been widely commented upon; it was substantiated, e.g., that the issuer of the first document, Mściwoj from Strońsko, was not holding the office of the castellan of Bydgoszcz (that is, a land office), but was the deputy of the Starost - the Burgrave of Bydgszcz. 